\title{
Value Chain Analysis and Attractiveness of the Telecommunications Industry in Mongolia
}

\author{
Tsolmon Jambal ${ }^{1, *}$, Enebish Jambal ${ }^{2}$ \\ ${ }^{1}$ Institute of Technology and Business in České Budějovice, Faculty of Corporate Strategy, Okružní 517/10, 37001 České Budějovice, \\ Czech Republic \\ ${ }^{2}$ Mongolian University of Science and Technology, School of Business Administration and Humanities, 8th khoroo, Baga toiruu 34, \\ Sukhbaatar district Ulaanbaatar, Mongolia 14191, Mongolia
}

\begin{abstract}
During the 4th Industrial Revolution and the 3rd Wave of Digitalization, the telecommunications sector developed rapidly and played a key role in accelerating economic development and competitiveness. Researchers and experts point out that the sector is an important tool to directly and indirectly support the implementation of the 17 goals of the 2030 Sustainable Development Goals. In this context, a demand it is important for the information and communications technologies (ICT) companies to make strategic changes, modernize their business processes, analyse key technology operations, and evaluate the effectiveness of supply, human resources, financial, and management policies. In order to create a distinct competitive advantage, key activities in the sector, such as procurement, internal operations, and sales channels, will be strategically coordinated, and human resources, technology, finance, and management will be configured to assist. Therefore, industry-wide value chain analysis will explore the challenges related to the supply of information and communication raw materials, technology-based cooperation, and legal and regulatory issues. This research aims to assess the value chain of the telecommunication services and define the gaps, which are drawbacks of the development. This paper will be a foundation for further studies on industry profitability and competitiveness by focusing on the areas that are essential to value creation in end-to-end services such as mobile communications, internet, and cable television.
\end{abstract}

Keywords: value chain; telecommunication; attractiveness of the industry; ICT; IT; Porter's value chain analysis

\section{Introduction}

Mongolia's information and communication sector, which is accounted for 2.4 percent of GDP, is dominated by the private sector, which has consistently implemented policies to promote privatization, market liberalization, and competition, increasing the sector's efficiency and revenue. The information and communication sector consists of a range of industries and services - Internet service provision, telecommunications equipment and services, information technology (IT) equipment and services, media and broadcasting, libraries and documentation centers, commercial information providers, network-based information services and other related information and communication activities [1]. Mongolia's telecommunications sector is a unique sector with different technological activities, such as fixed and mobile communications, internet, cable television, and postal services. For the telecommunications industry, assessing a value chain is important to see where the technology is creating value together, to see the coherence of core activities, and to make strategic decisions. According to Porter's study [2], it is clear that the most important role is played by information technology (IT); this has impacts both on differentiation and cost reduction, as it is the lever to create competitive advantage, to create new business, and to change the way firms operate. Few researchers performed Value chain analysis on the example of the PIM industry [3-5]. In this paper we introduce a literature review on historical development of value chain, next, a methodology of value chain assessment, at last, an assessment of value chain of Mongolian telecommunication industry. In this article, we look at the changes and innovations in the value chain theory and methodology, analyze the value chain of the telecommunications industry using M. Porter's generic value chain method, and make connections between technological activities.

\subsection{Development of the Value Chain concept}

The value chain concept and analysis were first described and initiated by Michael Porter [2]. Changes and innovations in value chain theory and methodology over the course of history have significantly enriched the methodology and techniques of generic value chain analysis from P. Porter's Generic Value Chain Analysis to 1985-1995 [3]. However, research articles since 1996 have developed The Value Network concept, and from 2000, the concepts of Global Value

\footnotetext{
* Corresponding author: jambal@mail.vstecb.cz
} 
Chain, Added Value Chain, and Sustainable Value Chain have made important contributions to the development of value chain theory. From this it can be concluded that the concept is in transition from the value chain to the value network. The table below shows the development of the value chain concept.

Table 1. Development of the Value Chain concept

\begin{tabular}{|l|l|}
\hline \multicolumn{1}{|c|}{ Approach to the concept of value chain } & \multicolumn{1}{c|}{ Autors } \\
\hline $\begin{array}{l}\text { Researchers who have enriched and developed } \\
\text { valuation techniques of value chains }\end{array}$ & $\begin{array}{l}\text { Porter and Victor [3], Davenport and Cronin [6], Hergert and } \\
\text { Morris [7], Shapiro et al. [8], Porter [9], Rayport and Sviokla } \\
\text { [10], Porter [11], Zhang et al. [12], Roper et al. [13] }\end{array}$ \\
\hline $\begin{array}{l}\text { Researchers who developed The Value Network } \\
\text { and the global value chains concept }\end{array}$ & $\begin{array}{l}\text { Porter [14], Achrol [15], Allee [16], Bovel and Martha [17], } \\
\text { Anderson [18] }\end{array}$ \\
\hline $\begin{array}{l}\text { Researchers studying value chain linkages and } \\
\text { interrelationships and Collaboration of } \\
\text { Sustainable Value Chain }\end{array}$ & Ensign [19], Dekker [20], \\
\hline $\begin{array}{l}\text { Researchers who have linked value chains to } \\
\text { operational management and business process } \\
\text { management. The Value Chain can be connected } \\
\text { to the concept of business process management }\end{array}$ & $\begin{array}{l}\text { Rainbird [21], Schweizer [22], Horne } \\
\text { [23], Bailey and Francis [24] }\end{array}$ \\
\hline $\begin{array}{l}\text { Researchers who studied The Added Value Chain } \\
\text { and Value network }\end{array}$ & $\begin{array}{l}\text { McPhee and Wheeler [25], Peppard and Rylander [26], Fearne } \\
\text { and Martinez [27], Guzmán et al. [28], Håkansson and Snehota } \\
\text { [29], Möller and Rajala [30], Allee [16], Fearne and Martinez } \\
\text { [27] }\end{array}$ \\
\hline
\end{tabular}

Source: Authors.

Value System encloses also the concepts of the Supplier Value Chain, Channel Value Chain and Buyer Value Chain. Inside the Value Chain the activities are not interdependent and, starting from the generic model of the Value Chain, it is therefore possible to shape a specific model for a particular firm. Strategy is defined by many authors as management, giving a precise direction or trajectory of activities towards a specific goal, which is formed in the business environment and is influenced by competitive and functional approaches. The literature suggests that strategic management is a set of instructions, decisions and actions that are necessary to achieve competitive advantage [31]. Management has the task of applying all these approaches in managing the overall composition of its activities [32]. As before but also today, strategy is understood as a science to plan and define the direction for action. It is not surprising that strategies were previously used in military actions and military operations. Above all, strategy should be an aid to decision making in the face of unclear or uncertain conditions. Shepherd, Souitaris and Gruber [5] conceptualize strategy as a management tool that can be used to build enterprise value in the long run. Porter points out that it is necessary to be able to properly set a strategy that carries within it the patterns that determine the competitiveness of the firm, such as internal objectives and the ways to achieve them. This is the essence of competitive strategy formulation in the relationship between the firm and its environment $[33,34]$. In 1939, a new approach to measuring and testing new competitive hypotheses was introduced, which is the positional approach [35,35]. The idea of this hypothesis is based on the concept of, that there is a relationship between performance and market structure. This is because the behaviour of business entities and buyers is based on performance, while the behaviour of business entities is based on market structure [37]. Porter [38] affirms that through this approach, businesses can achieve competitive advantages in the long run if they set and formulate the basic factors affecting the industry structure correctly. He follows this approach and recommends the use of the five forces model. Ongaro and Ferlie [39] also has a clear idea about the definition of strategy, which he summarises as and defines it using the 5Ps. According to him, every strategy needs to start with a plan, which in corporate management terms is referred to as a single, comprehensive and integrated plan designed to ensure the achievement of corporate objectives. Porter attaches importance and significance to complots, where false information is sent to competitors in order to create fear in them and thereby discourage them from taking certain actions [14]. Another point is the position focusing on the firm's view of the environment both outward and inward. The last point will state the character of the enterprise, which reflects the enterprise in such a light as the personalities of the people acting on the enterprise [30]. If the idea of Horne [23] and his need for strategic thinking will be continued, according to Lu, Liu and Falkenberg [40], strategic thinking is not only about thinking about strategy in the context of strategic management, but it is a way to continually look for ways to and how to improve the characteristics of strategic planning. However, he also points out that overanalysing and looking for solutions at any cost can only lead to worse and confusion. Müller, Marius and Buliga et. al. [41] has two perspectives on strategic thinking. The first view is that he views strategy as an intelligent tool that, when set up correctly, can identify a clear plan. The second view is that he views it as an intelligent imagination that is undoubtedly needed to create a clear idea. In the words of Bechtel and Jayaram [42], the most important condition for the elaboration of strategy is the understanding of the principles of strategic thinking, which includes the principle of variance, which notes that the strategic period in the long term cannot be estimated in advance, so how unexpected changes in the field of international politics can occur. Another point is the principle of permanence, which points out that strategy making is a never-ending process, and there is a need to constantly monitor the evolution of undeveloped strategies and the evolution of factors that may influence them. The principle of variation and the creative approach, whereby strategy-making should bear in mind that we are in a constantly changing environment that affects economic, political and social developments. It is therefore necessary to develop strategies in several versions. Cézanne, Lorenz and Saglietto [43] notes that a strategy developed 
yesterday may not be valid today or tomorrow. It should be kept in mind that a business should constantly come up with new approaches and adapt its products to meet the needs of the market, try to reduce costs, come up with new ideas, innovate and motivate its employees to perform better and better. It is essential to take into account the possibility of risk when drawing up strategies and everyone should be aware that risk can occur not only in our lives but in almost every corporate environment. If we focus on the definition of risk, we need to keep in mind what risks are and what they can cause. Risks can be viewed as a set of methods, procedures and predictions where the goal of management is to learn to anticipate them, estimate them, know how to deal with them and above all prevent them [44]. Risks can be measured according to several methods, one of which is the risk mapping method, which indicates areas with different levels of risk, based on a process indicating different types of hazards and vulnerability [45]. Currently, the business environment is subject to variability, caused by economic and political circumstances. It sheds new light on the issue of business risk management [46]. Different methods are used for risk assessment and principles, which include the use of statistical methods to assess, for example, the level of financial security of a business using cost theory. Such a method can be referred to as Enterprise Risk Management, which manages risks in an integrated holistic manner [47,48]. The purpose of any enterprise is to create a quality product with a special value for a specific market. In order to navigate the business environment clearly, all decisions should be based on the observed results of the situation of the internal and external environment. Therefore, in order to achieve to make the right decision, the right steps need to be taken, and it is this analysis of the business environment that is the crucial step for the strategic manager to take. One of the main elements distinguishing the work of a strategic manager from that of a business project manager is the confrontation of the intention with the environment [49]. The reasons why the business environment must be analysed are simple. It is for the reason of being able to identify and determine the position of the business in the market in which it operates, to be able to respond effectively to changes, to estimate its potential, to be able to predict the behaviour of customers and competitors and to be able to identify risks.

\section{Methodology}

A theoretical framework of "Value Chains and Competitive Advantage" and a basic methodological model on the concept of value chain have been developed by M. Porter in his publications such as "Competitive Advantage of Creating and Sustaining Superior Performance [2] and Cases in Competitive Strategy [33].

\subsection{Porter's value chain analysis}

Every company is a collection of activities that are performed to design, produce, market, deliver and support its products. All these activities cab be represented using a value chain, shown in Figure 1. The value chain displays total value, and consists of value activities and margin. Value activities are the physically and technologically distinct activities a firm performs. Margin is the difference between total value and the collective cost of performing the value activities. M. Porter's Generic value chain consists of nine parts of activities that are connected to each other in their own unique ways. It consists of two groups: main functions of the value chain and supporting functions. Value activities can be divided into two broad types, primary activities and support activities. Primary activities are the activities involved in the physical creation of the product and its sale and transfer to the buyer (Figure 1).

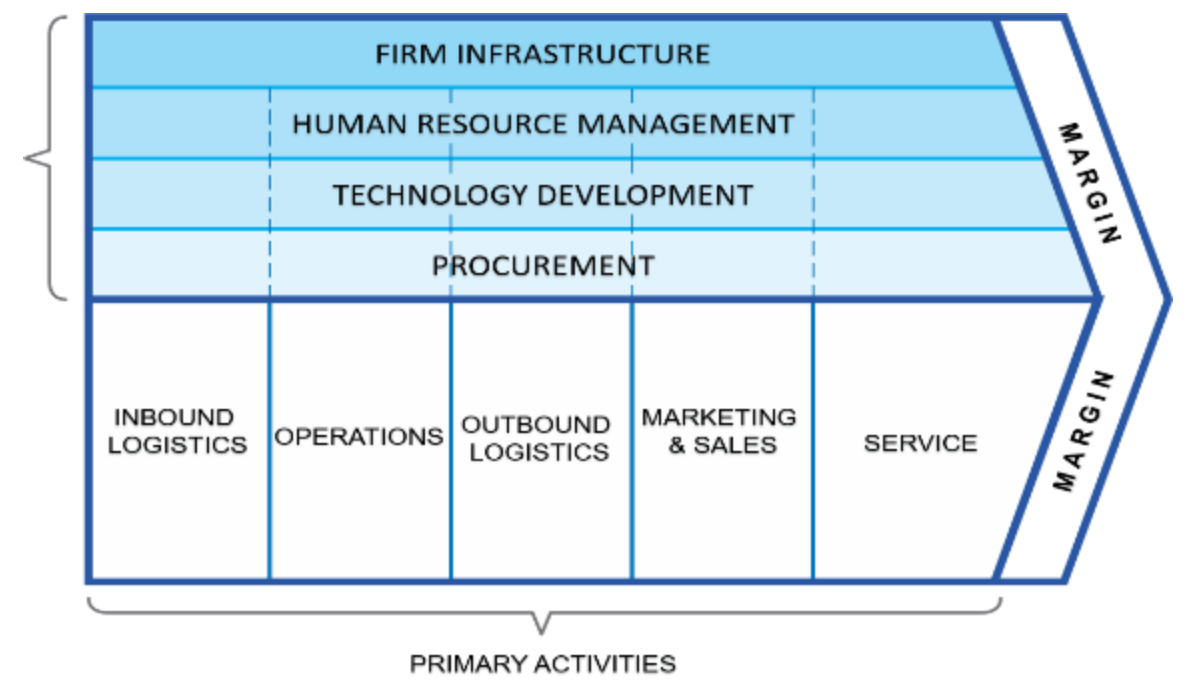

Figure 1. The generic value chain model adapted from Porter

Source: Authors based on [2].

Primary activities can be divided into five generic categories: Inbound logistics, operations, Outbound logistics, Marketing and Sales and Service. Each category is vital to competitive advantage depending on the industry. Support 
activities involved in competition of any industry are divided into four generic categories: Procurement, Technology development, Human resource management, Firm Infrastructure. Primary and Support activities have different roles in competitive advantage.

Table 2. Methodology of the Value chain analysis

\begin{tabular}{|l|l|}
\hline \multicolumn{2}{|l|}{ Methodology of the Value chain analysis } \\
\hline $\begin{array}{l}\text { Starting with the generic chain, individual value activities are identified into industry. Each generic category can be divided into } \\
\text { discrete activities. Important Steps in Value Chain Analysis Methodology: }\end{array}$ \\
\hline $\mathbf{1}$ & $\begin{array}{l}\text { The value is assessed by starting from the general chain, in other words, outline independent value operations are performed } \\
\text { toward delivering final services to an end-user. }\end{array}$ \\
\hline $\mathbf{2}$ & $\begin{array}{l}\text { Determine whether operations completed by themselves or outsourced from another organization independently or in } \\
\text { collaboration. }\end{array}$ \\
\hline $\mathbf{3}$ & Independent technological and economic activities must be separated. \\
\hline $\mathbf{4}$ & Mapping the Value Chain. Describe the sequence of activities along the flow of the process. \\
\hline $\mathbf{5}$ & Let's see how it affects the difference. \\
\hline $\mathbf{6}$ & Activities are classified according to their contribution to the cost. \\
\hline $\mathbf{7}$ & Formulate research questions [4]. \\
\hline
\end{tabular}

Source: Authors.

\subsection{Analysis of the attractiveness of the industry}

The analysis of the attractiveness of the industry is evaluated using a grid with 15 factors and the forces that affect them are assigned a score from 1 to 10. A higher score (10) is assigned when the conditions in the industry are maximized in terms of available resources. Otherwise, the point score is low, where the company is unable to meet its obligations in the industry. The optimal point score range is from 75 to 120 points. A score lower than 75 points signals the need for acute repositioning of the company within the industry, for example by entering a new segment [50]. Place the figure as close as possible after the point where it is first referenced in the text. If there is a large number of figures and tables it might be necessary to place some before their text citation.

\section{Results and Discussion}

\subsection{Telecommunication and Information technology sector in Mongolia}

Total revenue of the sector reached 1,274.1 billion MNT in the quarter of 2019, which is $14 \%$ higher than that of the same period of the previous year. Revenues from mobile services, which account for more than 50 percent of this revenue, increased by 0.7 percent from the same period of last year, while revenues from IP TV and Internet wholesale services decreased by 1.4 to 2.3 percent [51]. A total of 6,675 people work in the sector, of which 827 are engineers and technicians, accounting for $12.3 \%$ of the total workforce [52].

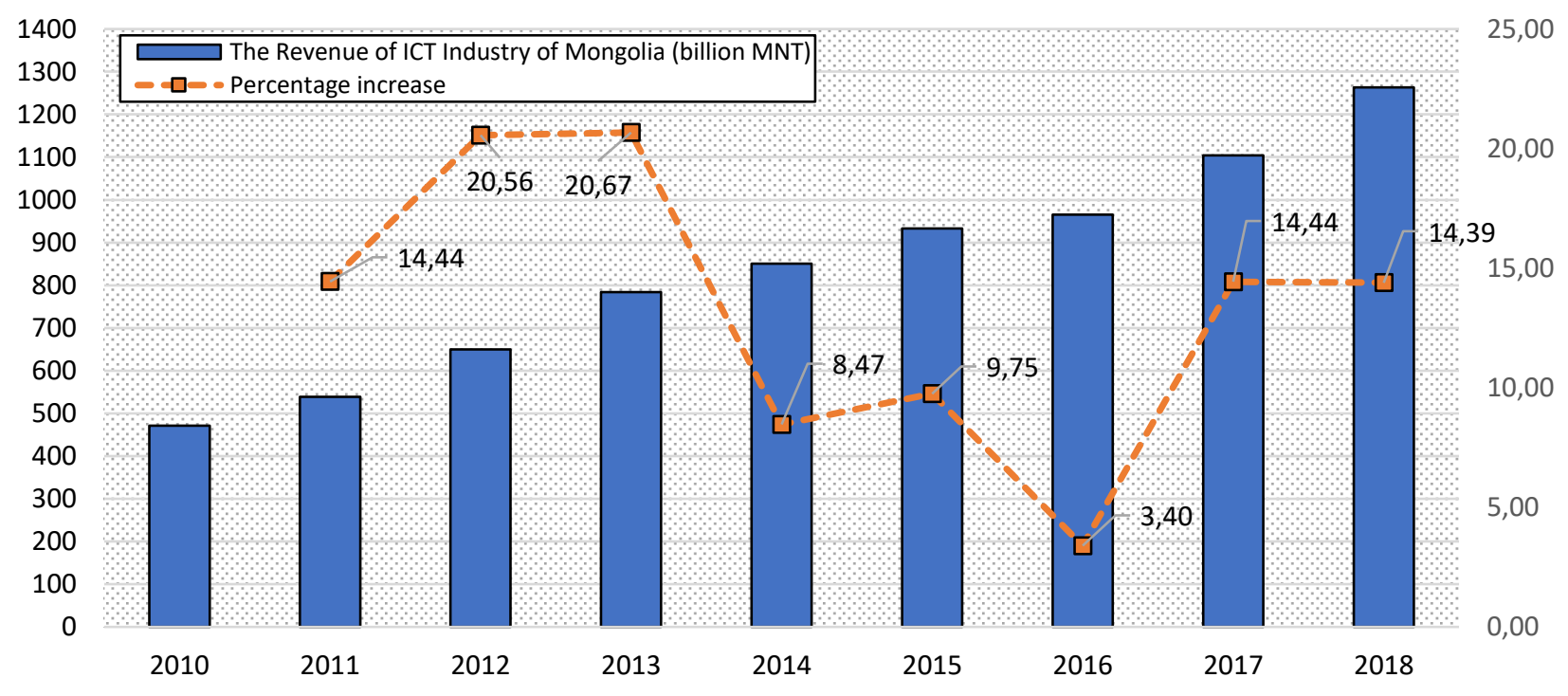

Figure 2. The Revenue of ICT industry of Mongolia (billion MNT)

Source: Authors based on [29].

Mobile and landline telephone services: The number of users of a new type of landline services, the Internet-based triple play service (IPTV), increased by $5.8 \%$, contributing to a total increase of $1.1 \%$ in landline services. 
Internet services: The total number of Internet users increased by $10.1 \%$ to 2.65 million compared to the same period of the previous year, which is 91.3 percent of the population. This is due to $3 \mathrm{G}$ and $4 \mathrm{G}$ mobile networks, provided by 67 companies licensed to provide Internet services in Mongolia. 2.45 million or $93 \%$ of customers are mobile users and 231.1 thousand are landline users.

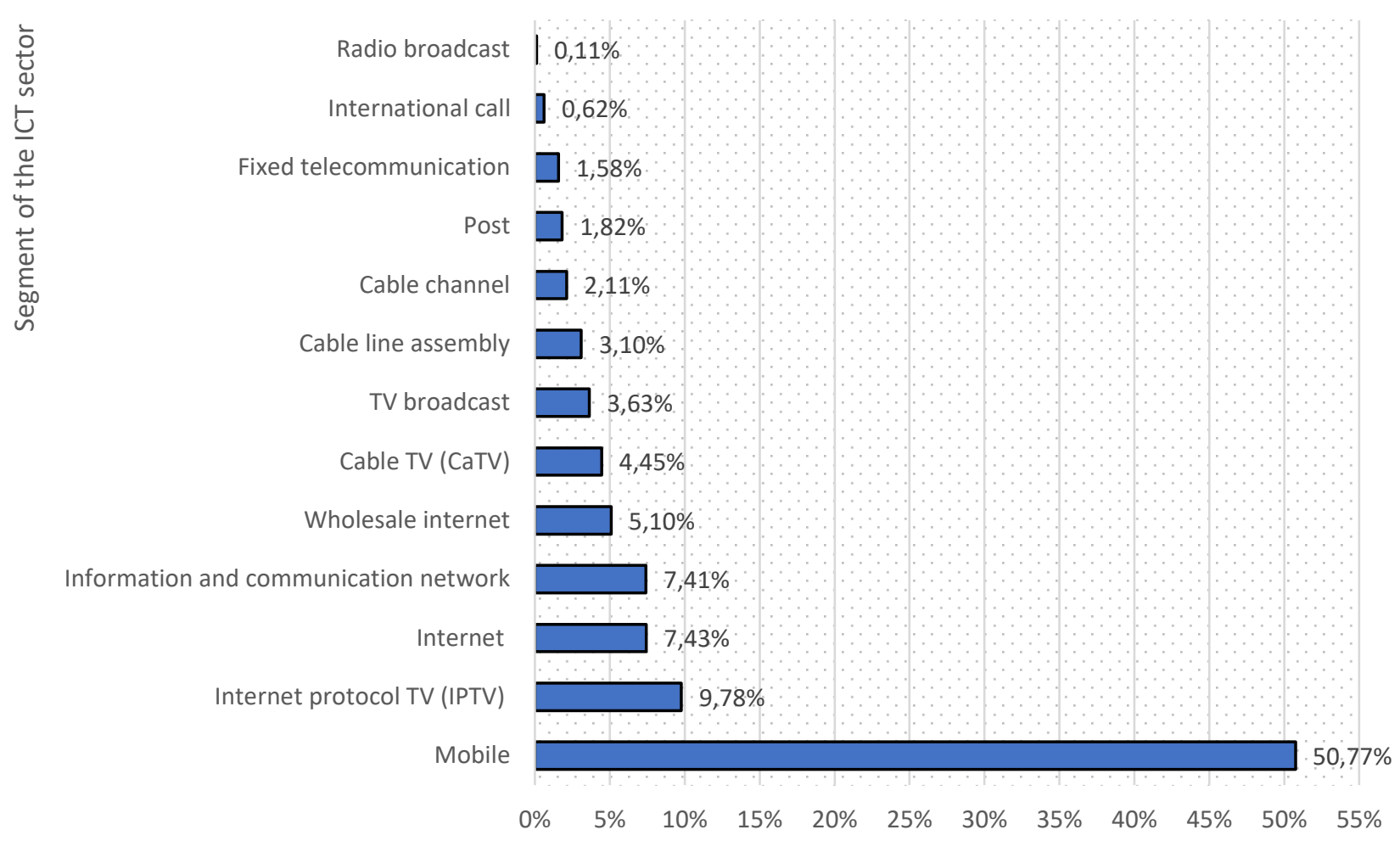

Percentage composition

Figure 3. Composition of individual segments of the telecommunications and information technology sector

Source: Authors.

Software production and information technology: There are more than 3,000 companies operating in the field of software production and information technology, of which $95.1 \%$ are companies operating in the field of communication and information technology. Including companies with foreign investment, this figure is $97 \%$. Cable TV service: According to a report by NSO-MN in 2019 the number of multi-channel TV service users increased by $6.8 \%$ compared to the same period of 2018 and reached 1,047,000. 57\% of the total consumption is in Ulaanbaatar and $43 \%$ in rural areas [51]. Transmission network: Mongolia is connected to more than 195 countries via Intelsat, APSTAR-5 satellite, fiber optic cable and radio relay lines. As of 2019 there are 37,646 km of fiber-optic cable in Mongolia and 6,294 km in urban areas. Postal service: In our country, revenues from express mail, parcels, packages and logistics services have increased in recent years and as of 2019, accounted for 1.6 percent of the total revenue of the sector [51].

\subsection{Value chain of the Mongolian telecommunication and Information technology sector}

An overview of the value chain of telecommunications industry reveals that the industry is competing with the same technology in networking and cabling, which is part of the core business. However, in Outbound Logistics, Marketing and Sales and Service parts the industry has differences and variety of companies are competing for a market share. This is shown in Fig 4. 
I. Fixed telephone (Total 8)

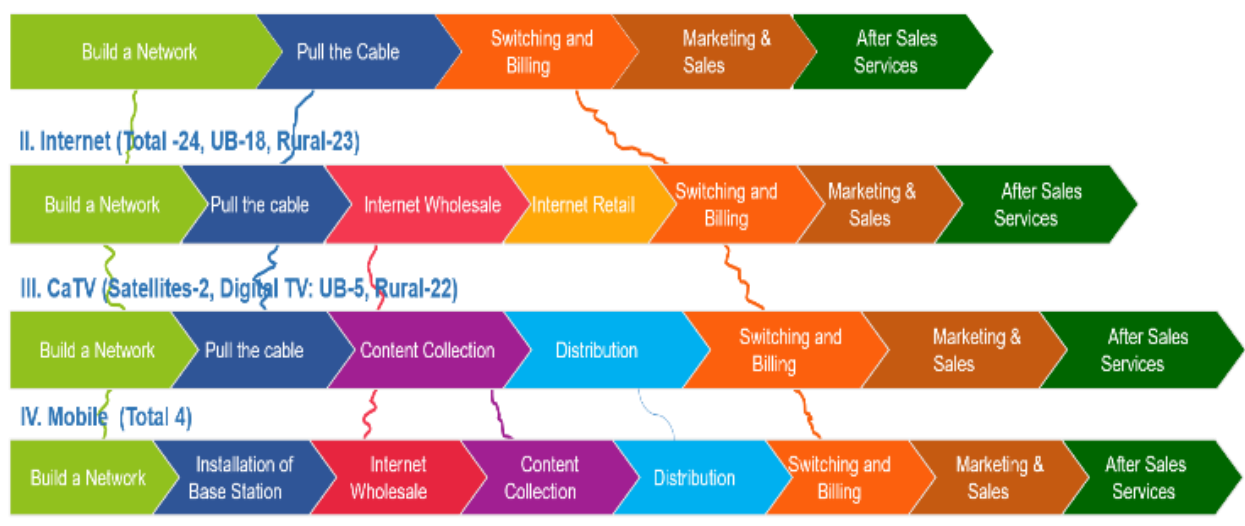

Figure 4. Value chains in the information and communication sector

Source: Authors.

Among others we want to emphasis postal services industry of Mongolia. The focus of the postal industry is the continuous improvement of incoming and outgoing processing as part of the development of the postal network and the maintenance of the network's continuity. There is also a need to pay attention to the development of transportation and logistics, the security of postal items, the timing of inspections and the quality of delivery.

\section{Post Service (Post -5, International express post -7, Logistic-6, Delievery-40, VAS-17)}

\begin{tabular}{|c|c|c|c|c|}
\hline Receive Mail and Parcels & Sort Out & $\begin{array}{l}\text { Send Shipping } \\
\text { Logistics }\end{array}$ & $\begin{array}{l}\text { Marketing and } \\
\text { Sales }\end{array}$ & $\begin{array}{l}\text { Distribution and } \\
\text { Delivery }\end{array}$ \\
\hline
\end{tabular}

Figure 5. Postal service value chain

Source: Authors.

Note: VAS - Value added service.

According to Figure 5, in the case of postal services, it is preferable to implement a different strategy for the main operations, transport and logistics operations, and distribution services to end users.

\subsection{Analysis of the attractiveness of the telecommunications and information industry in Mongolia}

The analysis of the attractiveness of the sector was carried out in the Mongolian telecommunications and information sector. The analysis included an assessment of individual factors and strength according to a score from 1 to 10 points based on a subjective assessment (see Table 2).

Table 3. Font styles for a reference

\begin{tabular}{|c|c|c|c|}
\hline \multicolumn{2}{|c|}{ Factor } & Potency & Score \\
\hline $\mathbf{1}$ & Growth potential & Growing demand & 7 \\
\hline $\mathbf{2}$ & Market diversity & Number of segments & 7 \\
\hline $\mathbf{3}$ & Profitability & Rising / stagnant / declining & 8 \\
\hline $\mathbf{5}$ & Expansion & Competitors, inflation & 5 \\
\hline $\mathbf{5}$ & Concentration & Number of dominant enterprises & 7 \\
\hline $\mathbf{6}$ & Sales & Cyclic, continuous & 6 \\
\hline $\mathbf{7}$ & Specialization & Value, quality, substitution & 7 \\
\hline $\mathbf{8}$ & Brand & Channels, need for support & 6 \\
\hline $\mathbf{9}$ & Distribution & Experience effect, elasticity & 5 \\
\hline $\mathbf{1 0}$ & Pricing policy & Competitive, high / low cost & 8 \\
\hline $\mathbf{1 2}$ & Cost position & Guarantee, reliability & 5 \\
\hline $\mathbf{1 3}$ & Services & Leadership, uniqueness & 8 \\
\hline $\mathbf{1 4}$ & Technology & Vertical, horizontal, control & 6 \\
\hline $\mathbf{1 5}$ & Integration & Industry barriers & $\mathbf{9 8}$ \\
\hline \multicolumn{2}{|l|}{ Possibility of entry and exit } & Total & \\
\hline
\end{tabular}

Source: Authors. 
Growth potential: In the last decade, ICT revenues in Mongolia have grown by an average of $13.26 \%$ year on year. As a result, the use of telecommunications products and services such as mobile and fixed telephones, the Internet, cable television and postal services can be expected to continue to grow.

Market diversity: Telecommunication products and services are widely used in other industries. In this way, they reach many segments and create new opportunities for innovation.

Profitability: Companies operating in the industry are currently attractive in terms of overall corporate profits.

Expansion: The direct impact of inflation is unpredictable due to the high demand for telecommunications services, but there is considerable competition in this sector. New application-based software companies are particularly attractive. The attractiveness of the industry is assessed as above average.

Concentration: The concentration in the telecommunications sector represents 4 dominant mobile operators, which represent more than 50 percent of the sector's total revenue. Small, weak companies have difficulty entering the market, and even though they are strongly attracted. State regulation, obtaining a license and high investment form a major barrier to entry in this market.

Sales: The use of telecommunications products and services in the telecommunications industry is on the rise due to the current situation of COVID-19.

Specialization: In this area you can find many different groups of products and services, which are very different from each other. But the products and services in a given group are not so different.

Brand: There are a number of dominant companies with established brands (Mobicom, Skytel, Unitel, Gmobile) on the market, whose products and services are popular with consumers, but do not guarantee higher quality. Software small companies provide services through their already established $3 \mathrm{G}$ and $4 \mathrm{G}$ networks or channels.

Distribution: Distribution channels are created through our own established networks and online form. Recently, the post office has become more of a delivery service due to Covid.

Pricing policy: Due to the high level of competition in the market, companies often have a low pricing policy. In recent years, this has become increasingly common on the Internet. Products and services are delivered as complete as possible. Low-cost companies make the sector more attractive with lower prices, but they also face higher costs compared to strong competition.

Cost position: Dominant companies have a cost advantage over small companies due to their high capital potential. Due to the rapid pace of technological innovation, the costs of technological innovation and new investment are high. In recent years, the fact that software development companies have entered the industry at relatively low cost has been rated as moderately attractive.

Services: As already mentioned, there are many types of products and services in this sector. Mobile communication services dominate. The industry tends to be competitive in terms of services, and focuses on after-sales service by providing multiple sets of packages.

Technology: Due to the rapid pace of technological change, significant investment is needed to ensure the professional development of employees in the telecommunications sector in Mongolia.

Integration: Vertical and horizontal integration is considered. Horizontal integration takes place by merging small companies with dominant ones. In the telecommunications sector, start-ups have been cooperating with large companies in recent years. This is beneficial for both parties when introducing new products and services.

Possibility of entry and exit: Barriers to this sector are mainly high competition from large companies (enterprises) and increased demands on initial capital. For these reasons, firms (businesses) may not be interested in entering the industry.

\section{Conclusion}

Value chain analysis in the Mongolian ICT sector is important in defining strategies for gaining or strengthening the competitive advantage of industries in this sector. As industries in the industry often localize high technology from the outside, they make a difference in the field of Outbound logistics, Marketing and Sales and Service operations. In the case of postal services, the quality and performance received by end-users are affected by the difficulties in the basic operations of transport and logistics of distribution to end users. Internet, telephone and how is this linked to activities in different sectors. The telecommunications and information sector in Mongolia scored 97 points in the analysis of the attractiveness of the sector. The total average value is 6.53 , which can be described as an average satisfactory value. Unsatisfactory values were achieved in the areas of concentration factors, distribution, cost position and technology. On the contrary, diversity, expansion, services and integration seem to be very attractive among the researched factors. With regard to the future in terms of the attractiveness of the industry, the possibility of new unforeseen small start-ups can enter the industry. Furthermore, value chain analysis would be very effective in tracing product flows, showing the value 
adding stages, identifying key actors and the relationships with other actors in the chain. The results of this study contribute to the research and practice of value chain management by improving predictive and reactive decisions to take advantage of $\mathrm{VC}$ model visualization and analysis of the attractiveness of the telecommunications and information industry in Mongolia.

\section{References}

1. J. Onjala, D. McCormick. Methodology for Value Chain Analysis in ICT Industry Frameworks for the Study of Africa. Asian Drivers. (2007)

2. M. E. Porter. Competitive Advantage, Creating and Sustaining Superior Performance, First free. New York City: A Division of Simon \& Schuster Inc. ISBN 0-684-84146-0 (1998)

3. M. E. Porter, E. M. Victor. How information gives you competitive advantage. Harvard Business Review. 63, 149160 (1985)

4. J. Peppard, A. Rylander. From value chain to value network: insight from mobile operators. European Management Journal. 24, 128-141 doi.org/10.1016/j.emj.2006.03.003 (2006)

5. D. A. Shepherd, V. Souitaris, M. Gruber, MCreating New Ventures: A Review and Research Agenda. Journal of Management. 47(1), 11-42 doi.org/10.1177/0149206319900537 (2021)

6. L. Davenport, B. Cronin. Strategic information management: forging the value chain. International Journal of Information Management. 8, 25-34 doi.org/10.1016/0268-4012(88)90005-9 (1988)

7. M. Hergert, D. Morris. Accounting data for value chain analysis. Strategic Management Journal. 10(2), 175-188 doi.org/10.1002/smj.4250100207 (1989)

8. J. M. Shapiro, V. M. Singhal, S. N. Wagner. Optimizing the value chain. Interfaces. 23, 102-117 doi.org/10.1287/inte.23.2.102 (1993)

9. M. E. Porter. Towards a dynamic theory of strategy. Strategic Management Journal. 12, 95-117 doi.org/10.1002/smj.4250121008 (1991)

10. J. F. Rayport, J. J. Sviokla. Exploiting the virtual value chain. Harvard Business Review. 73, 14-24 (1995)

11. M. E. Porter. Strategy and the internet. Harvard Business Review. doi.org/10.1109/ICSSSM.2007.4280087 (2001)

12. Q. Zhang, M. A. Vonderembse, J. S. Lim. Value chain flexibility: a dichotomy of competence and capability. International Journal of Production Research. 40, 561-583 doi.org/10.1080/00207540110091695 (2002)

13. S. Roper, J. Du, J. H. Love. Modelling the innovation value chain. Research Policy. 37, 961-977 doi.org/10.1016/j.respol.2008.04.005 (2008)

14. M. E. Porter ME What is strategy? Harvard Business Review. 74, 61-78 (1996)

15. R. S. Achrol. Changes in the theory of interorganizational relations in marketing: toward a network paradigm. Journal of the Academy of Marketing Science. 25, 56-71 doi.org/10.1177/0092070397251006 (1997)

16. V. Allee. Reconfiguring the value network. Journal of Business Strategy. 21(4), 36-39 doi.org/10.1108/eb040103 (2000)

17. D. Bovel, J. Martha. From supply chain to value net. Journal of Business Strategy. 21, 24-28 doi.org/10. 1108/eb040101 (2000)

18. S. C. Anderson. The globally competitive firm: functional integration value logistics global marketing and business college strategic support. Competitiveness Review. 10, 33-45 doi.org/10.1108/ eb046397 (2000)

19. P. C. Ensign. Value chain analysis and competitive advantage: assessing strategic linkages and interrelationships. Journal of General Management. 27(1), 18-42 doi.org/10.1177/030630700102700102 (2001)

20. H. C. Dekker. Value chain analysis in interfirm relationships: a field study. Management Accounting Research. 14, 1-23 doi.org/10.1016/S1044-5005(02)00067-7 (2003)

21. M. Rainbird. A framework for operations management: the value chain. International Journal of Physical Distribution \& Logistics Management. 34, 337-345 doi.org/10.1108/09600030410533628 (2004)

22. L. Schweizer. Concept and evolution of business models. Journal of General Management. 31, 37-56 doi.org/10. 1177/030630700503100203 (2005)

23. J. R. Horne. Are you seeing the big picture in selecting your improvement projects? TQM Journal. 26, 658-666 doi.org/10.1108/TQM-08-2013-0094 (2014) 
24. K. Bailey, M. Francis. Managing information flows for improved value chain performance. International Journal of Production Economics. 111(1), 2-12 doi.org/10.1016/j.ijpe.2006.11.017 (2008)

25. W. McPhee, D. Wheeler. Making the case for the added-value chain. Strategy \& Leadership. 34(4), 39-46 doi.org/10.1108/10878570610676873 (2006)

26. J. Peppard, A. Rylander. From value chain to value network: insight from mobile operators. European Management Journal. 24, 128-141 doi.org/10.1016/j.emj.2006.03.003 (2006)

27. A. Fearne, M. G. Martinez. Dimensions of sustainable value chains: implications for value chain analysis. Supply Chain Management. 17(6), 575-581 doi.org/10.1108/13598541211269193 (2012)

28. J. Guzmán, P. Moreno, P. Tejada. The tourism SMEs in the global value chains: the case of Andalusia. Service Business. 2, 187-202 doi.org/10.1007/s11628-008-0034-6 (2008)

29. H. Håkansson, I. Snehota. No business is an island: the network concept of business strategy. Scandinavian Journal of Management. 22, 256-270 doi.org/10.1016/j.scaman.2006.10.005 (2006)

30. K. Möller, A. Rajala. Rise of strategic nets - new modes of value creation. Industrial Marketing Management. 36, 895-908 doi.org/10.1016/j.indmarman.2007.05.016 (2007)

31. R. E. Hoskisson, F. Chirico, J. Zyung, E. Gambeta. Managerial Risk Taking: A Multitheoretical Review and Future Research Agenda. Journal of Management. 43(1), 137-169 doi.org/10.1177/0149206316671583 (2017)

32. T. Saebi, L. B. Lien, N. J. Foss. What Drives Business Model Adaptation? The Impact of Opportunities, Threats and Strategic Orientation. Long Range Planning. 50(5), 567-581 doi.org/10.1016/j.lrp.2016.06.006 (2017)

33. M. E. Porter. Cases in Competitive Strategy. New York City: A Division of Simon \& Schuster Inc. ISBN 0-68484148-7 (1982)

34. E. G. Carayannis, E. Grigoroudis, M. Del Giudice, M. R. Della Peruta, S. Sindakis. An exploration of contemporary organizational artifacts and routines in a sustainable excellence context. Journal of Knowledge Management. 21(1), pp. 35-56 doi.org/10.1108/JKM-10-2015-0366 (2017)

35. M. E. Porter, E. M. Victor. How information gives you competitive advantage. Harvard Business Review. 63, 149$160(1985)$

36. C. Lomberg, D. Urbig, C. Stöckmann, L. D. Marino, P. H. Dickson. Entrepreneurial Orientation: The Dimensions' Shared Effects in Explaining Firm Performance. Entrepreneurship Theory and Practice. 41(6), 973-998 doi.org/10.1111/etap.12237 (2017)

37. P. M. Kreiser, B. S. Anderson, D. F. Kuratko, L. D. Marino. Entrepreneurial Orientation and Environmental Hostility: A Threat Rigidity Perspective. Entrepreneurship Theory and Practice. 44(6), 1174-1198 doi.org/10.1177/1042258719891389 (2020)

38. M. E. Porter. Competitive advantage, creating and sustaining superior performance. New York: The Free Press. ISBN 0-02-925090-0 (1985)

39. E. Ongaro, E. Ferlie. Strategic Management in Public Organizations: Profiling the Public Entrepreneur as Strategist. The American Review of Public Administration. 50(4-5), 360-374 doi.org/10.1177/0275074020909514 (2020)

40. H. Lu, X. Liu, L. Falkenberg. Investigating the Impact of Corporate Social Responsibility (CSR) on Risk Management Practices. Business \& Society. 61(2), 496-534 doi.org/10.1177/000765032092898 (2020)

41. J. M. Müller, O. Buliga, K.-I. Voigt 2018. Fortune favors the prepared: How SMEs approach business model innovations in Industry 4.0. Technological Forecasting and Social Change. 132, 2-17 doi.org/10.1016/j.techfore.2017.12.019 (2018)

42. C. Bechtel, J. Jayaram. Supply Chain Management: A Strategic Perspective. New Zealand Journal of Crop and Horticultural Science. 47(4), 15-34 doi.org/10.1108/09574099710805565 (2019)

43. C. Cézanne, E. Lorenz, L. Saglietto. Exploring the economic and social impacts of Industry 4.0. Revue d'économie industrielle. 1(1), 11-35 doi.org/10.4000/rei.8643 (2020)

44. O. F. Bustinza, E. Gomes, F. Vendrell-Herrero, T. Baines. Product-service innovation and performance: the role of collaborative partnerships and R\&D intensity. $R \& D$ Management. 49(1), 33-45 doi.org/10.1111/radm.12269 (2019)

45. W. Viriyasitavat, L. D. Xu, Z. M. Bi, A. Sapsomboon. Blockchain-based business process management (BPM) framework for service composition in industry 4.0. Journal of Intelligent Manufacturing. 31(2), 1737-1748 doi.org/10.1007/s10845-018-1422-y (2020) 
46. A. Prosvetova, E. Dozhdeva, V. Manyaeva, O. Belyakova. Risk Management In The Process Of The Financial Activity Of The Corporation. Global Challenges and Prospects of the Modern Economic Development. 57, 11691175 doi.org/10.15405/epsbs.2019.03.118 (2019)

47. L. Hahnenstein, G. Köchling, P. N. Posch. Do firms hedge in order to avoid financial distress costs? New empirical evidence using bank data. Journal of Business Finance \& Accounting. 48(3-4), 718-741 (2021)

48. M. Altuntas, T. R. Berry-Stölzle, R. E. Hoyt. Enterprise Risk Management Adoption and Managerial Incentives. Journal of Insurance Issues. 43(2), 1-42 (2020)

49. M. J. Sousa, Á. Rocha. Skills for disruptive digital business. Journal of Business Research. 94, 257-263 doi.org/10.1016/j.jbusres.2017.12.051 (2019)

50. J. Tichá, I. Hron. Strategické ř́zení. Praha: Česká zemědělská univerzita v Praze. ISBN 978-80-213-0922-7 (2016)

51. CRC. CRC statistik of Mongolia 2019 [online]. Available at: https://crc.gov.mn/ (2019)

52. Communications and Information Technology Authority (CITA). CITA-Human Resource Research Report. (2018) 